\title{
MISCELLANEOUS NOTES.
}

Axwual Mretrixu.--In accordance with the Act of lncorporation, the annual meeting of the Entomological Society of Omario will be held at Kingston, Ont., on Wednesday evening, Sept. $27 \mathrm{th}, 187 \mathrm{r}$, when the annual Report will be read, with the Treasurer's statement. and officers for the ensuing year will be elected.-Fu. CAX. Fxr.

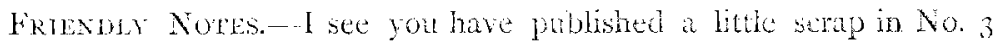
Cax. Ext., "by C. V. Riley, State Entomologist of Missonri, St. Louis." I had to laugh at the mountain you have made of the mole heap, and, in future, if you care to use any of my scribhlings in print, 1 must insist that you follow copy, and omit the "handles." I have no particular fondness for the latter, and they seem to be esperally out of place at the head of trifing communications.

While spending a few hours with Mr. Sculder, recently, I found, upon comparing notes, that he had not observed the difference in length in the larval horns of Disifpus and Crsula, and that, if anything, his descriptions made those of the former longer thin those of the latter-or the exact converse of what I described in the artich above referred to. I mention this fact that you may note it in your future observations, and perhitps it would be well to call attention to it in the Cx. Fxr., that others may also give us their experience. Mr. Scudder had, however, remarked the differences in the pupal humps; Lut, in describing, he speaks of the "posterior and anterior sides" of this hump instead of " npper and lower edges"--thereby imagining the pupa in a detached und horizontal, instead of the suspended vertical position as I have lone. Mr. Scudder has noticed some other differences in the two purpe, and I draw your attention to these differences, in order that you may make further comparisons. He finds that, while in Crsutc the shoulder (basal wing tubercle) is ronded off and partially suppressed, in Disipfis it is produced into a minute conical point, directed ontwards (and in Athcmis [one specimen oniy observed] less pointed and directed backwards). In Disiphes he finds the dorsal portion of the "anal loutton," within the joarginal ridge, to be longer than wide, white it i, more nearly square in Crould. He also thinks the latter is al little stouter and more constricted at the mesothorax, riewed dorsally from an examination of several cmpty puja shells of both species, I chubt whether any of these characters, taken singly, are of as much vituce as those I have given, lut they will all help us to separate 
the two species in their preparatory stages. Characters of single specimens are of little value, and true distinction can only be arrived at by the examination of many individuals. Thus, I possess one Ursula pupa, so conspicuously marked with black spots and streaks on the edges of the dorsal hump, of the wing and leg sheaths, of the shoulder, and of the ear-like prominences of the head, that, taken singly, these would form striking characters : but in others, again, these marks are either illy defined, or entirely cbsolete.

I am really rejoiced to see your little work prospering so well and improving so much. I am glad to see that Mr. V. 'T. Chambers is taking up the Micros. It is a rast and most interesting field, and I hope Mr. C. will prove a second Clemens to us, for we are sadly in need of one: There is something raher incoherent in Mr. Wm. Couper's articles, and he has committed some scrious crrors. Firstly, if he wishes to instruct in Entomology, he must not talk of the "family of Hymenoptera" (p. 35 , 1. 24). Secondly, he onght to know that curculionidons larvae do not spin siken cocoons; and by reerring to the third Missouri Entomological Report, he will find that we do know something of the habits of quite a number of our snoutbeetles. The larva in acoms which he describes on parge $G_{5}$ is, as I am quite convinced from his text, no Curculionid at all, but an inquilinous moth-larva, in which he has rather carelessly overlooked the legs. It produces a litrle ish-gray moth, characterized chiefly by having on the front wings two distinct discal spots on an usually silvery gray ground, and a transverse pale stripe across the basal third of the wing, well relieved pusteriorly by a dark median shade. It varies much in size and conspicuity of markings, but the average expanse is about $3 / 4$ ths of an inch. The moths issue all along from the end of April till Sept. The larva is found in all kinds of acorns, especially in those that have been injured or infested by the acom weevil (Balanimus rectus, Say), and the smail [it is generally 0.05 inch in diameter] circular hole, observed by Mr. Couper, and supposed by him to be made by the parent for the deposition of its $\operatorname{cgs}(1)$, is but the hole by which the Balaninus larva escaped to go into the ground, and which the inquilinous moth-larva covers up with silk after it comes to occupy the acorn. I took specimens of this moth to Europe with me, but could not find that it was described. It apparently belongs to the genus Gelechia, and I propose for it the name of $G$. glandulella. T have found its larva (in company with those of a 
Cecidomyia and of another Tineian) in acorns of Qucras ilicifolia which were still on the tree, and which were infested with a little pip-like gall, between the acorn and the cup.*

To one who has watched with interest, the writings of Messrs. Scudder, Lintner, and Edwards on Grapte interrogationis, Fabr., the article by the latter gentleman on page 70 , is extremely gratifying. From the fact, that in Europe, Grapta C-album shows three very distinct variations, and from my own breeding experience with interrogationis, 1 felt convinced that the black-winged and red-winged forms were but varieties of the one species, and so informed Mr. Lintner, over a year ngo. I am glad Mr. Edwards has anticipated me in demonstrating it in print. Such facts ought to give impetus to the rearing of insects; for though the artificial method of making species out of every little individual variation may be very amusing to those who choose to indulge in it, yet such work will never give us a natural system, and much of it will have to be undone by subsequent investigators who acquaint themselves with the adolescent as well as the perfect forms of a species.

St. Louis, Sept, roth, is $\$ 1$.

$$
\text { (․ Y. RHLT: }
$$

How TO PRESERYE ENHENERID .-. In drying, the color and form of Ephemericle soon change. Color is of little importance, cren in fresh examples: hut form is necessary to the distinguishing of the species. They are, thercfore, best preserved in a liquid. It is sufficient for ordinary purposes to dip the fresh killed specimen into diluted spirits, and then transfer it to a tube, or homoepathic globule bottle, partly filled with water. Next, Prices glycerine is added to the water--one or two drops a day-until the bottle is gradually filled. A small drop of acetic acid may be added finally, to prevent the growth of mould. The name of the species may be written on the disk of the cork, the date and locality of capture round its side. Hind wings of the species of Baetis and Centroptilum should be mounted on slips of grass, for microscopical examination. Pinned specimens are often difficult to determine, in consequence of their shrinking: to card them is 10 render them fit for nothing.-.....ETox's Ephemerida.

* This little gail is undescribed. In company with Mr. H. F. Bassett, of Waterbury, Ct., I found it so abundant last month, that the acoms were very generally destroyed. Strange as it may appear. from observations made by $\mathrm{Mr}$. Bassett, this gall. will, in all probability, prove to be but the summer form of the wooly gall known as quercus operatos-so little do we know yet of some of Nature's secrets! 